\title{
Democracy and Poverty: A Lesson from Mongolia*
}

$$
\text { N. T uya (M ongolia) }
$$

$\mathrm{L}$ ater this month, Mongolia will host the $7^{\text {th }}$ ministerial conference of the Community of Democracies (CD), an intergovernmental forum of democracies formed in 2000 at the initiative of Bronislaw Geremek of Poland and Madeleine Albright of the United States. Several civil society events will accompany it.

The CD was launched at a conference in Warsaw in 2000, and its goals were announced in the Warsaw Declaration: strengthening democratic values and institutions, protecting human rights, and promoting civil society. The effort was to be undertaken both at the national level, by supporting one another in these endeavors, and at the global level through collaboration on democracy-related issues in international and regional institutions. The Warsaw Declaration also emphasized the interdependence between peace, development, human rights and democracy.

After 2000, however, despite a sustained schedule of meetings and statements, the CD never really took off. Democracy's progress worldwide had slowed in subsequent years, as noted in a number of surveys, including one by Freedom House. Celebrating its $10^{\text {th }}$ anniversary in Krakow in 2010, the CD acknowledged this state of affairs and through its Act of Recommitment to the Warsaw Declaration pledged to intensify its efforts to transform itself "into a unique forum for the world's democracies to promote and strengthen democracy on a global basis." To meet this objective, the CD began to retool itself by creating a permanent secretariat, launching a partnership initiative that focuses on assistance to specific countries and, on top of civil society, bringing young people, businesses, and parliamentarians into its dialogue on democracy.

The April, 2013 conference in Ulaanbaatar will be an occasion for the CD to further reinvigorate its agenda. Mongolia, which currently holds the CD presidency, offers a number of lessons to offer that could contribute to the organization's recommitment to its objectives, especially emphasis on the interdependence between poverty, development and democracy. This emphasis is important both as an immediate goal for the host country and as a larger goal for the $\mathrm{CD}$ as a whole.

\footnotetext{
* A Commentary by the Center for Northeast Asian Policy Studies at Brookings Institution
} 
The case of Mongolia on poverty and democracy is instructive. The country started transitioning to democracy over twenty years ago and, for almost as long, the rate of poverty has stood at 30 percent and above. In the 1990s, much of it could be attributed to the disruptions caused by changes in its political and economic system. Harsh weather has been an intermittent factor, too. But no significant progress has been registered in later years, when the economy has grown at an annual average of 9 percent in the past decade. The latest available figure (2011) shows that poverty still stands at 29.8 percent, despite the doubledigit economic growth in the past two years. The gap between poor and rich has continued to grow, and infrastructure has languished in a chronically decrepit state. Corruption, on the other hand, has continued to increase. Between 1999 and 2011, while the economy was growing, the country's corruption ranking has managed to drop from a place where it was comfortably ahead of some of its fellow post-communist countries in Europe to a dismal 120th place out of some 180 countries surveyed by Transparency International. The implications for democracy were grave: most reforms stalled, vote buying became a serious concern, and public trust in the institutions of democracy was shaken. In a survey conducted in June 2012, over 80 percent of respondents believed that government policies were "always" or "often" failing to solve their concerns, chief among them unemployment and poverty.

The lesson to be drawn from this experience is that, early on in the transition process, new democracies should put economic liberty and transparency on a par with other democratic values such as regular elections, rule of law, human rights, freedom of association and freedom of speech. Otherwise, a callous and corrupt government, sometimes voted in through dubiously "free and fair" elections, can use the trappings and rhetoric of democracy as a fazade while behind the scenes they engage in rent-seeking practices that can lead to a systemic entrenchment of corruption. In such a system political power is used for economic gain and economic gain is used for buying political influence. Few or no dividends go to the general populace. This results in persistent poverty among a large percentage of the population coupled with poor social services. Public enthusiasm or support for democracy wanes, democracy is eroded, therefore human rights are violated, and eventually democracy breaks down. Such scenarios are an early and real threat to democracy because the impoverished populace does not have the necessary tools - such as education or access to information-to fight back and, in most cases, is simply unfamiliar with the concept of demanding government accountability and responsiveness.

Early on, the $\mathrm{CD}$ emphasized this problem by stating in Warsaw that eradication of poverty is an "essential contributing factor to the promotion and preservation of democratic development" (2000). This emphasis should now be 
renewed. To do so, recommitment to the concept of interdependence between democracy and poverty found in the Santiago Commitment (2005) is essential. The Commitment stressed that democracy cannot be sustained without persistent efforts to eliminate extreme poverty and, vice versa, that the strengthening of democratic governance was "an essential component" of the efforts to alleviate poverty. Rooting out corruption that "corrodes democracy," as stated in Warsaw, is a central element of these efforts, and this stance was reaffirmed in the Krakow Plan for Democracy (2010). Poverty is as much a threat to a democracy as poor institutions in that it deprives people of their political voice preventing them from holding their governments accountable and responsive, and eroding public trust in the emerging institutions of democracy. The CD's Bamako Consensus (2007) addressed the issue of public trust: "persistent inequality and poverty can lead to low public trust in political institutions and vulnerability to undemocratic practices both of which are threats to democracy." Poverty is also an assault on human dignity which is why the Bamako Consensus also emphasized that democracy, development and human rights were mutually reinforcing.

This body of reasoning serves as a good foundation for the CD to contribute to the ongoing global debate on the post-2015 development agenda. This debate presents the $\mathrm{CD}$ with an opportunity to pursue its position that eradication of poverty and the consolidation of democracy are interdependent. The thematic session on Millennium Development Goals (MDGs) that is planned for the CD's meetings in Ulaanbaatar could therefore be seized as an occasion to launch substantive discussions on collaboration, in the coming years, with international organizations and civil society on ways to incorporate democratic governance in the post-2015 development agenda, or mainstream anti-corruption efforts into it, and ensure that this agenda adopts a human rights-based approach, addresses inequality and promotes social inclusion. Discussions could revolve around the issues raised in papers and notes by UN bodies and agencies and other actors, especially civil society, that call for encompassing human rights, democracy and good governance in an inclusive development agenda focused on poverty eradication. The ideas expressed at the global consultation on governance and the post-2015 framework could also be taken up.

The experience of Mongolia could also be looked at. Mongolia is one of two countries that have voluntarily added a ninth goal to its MDGs: Strengthen Human Rights and Foster Democratic Governance. While a welcome initiative, Mongolia's MDG 9 has not been a successful undertaking either in terms of its design and implementation; one of its targets, "zero tolerance for corruption," has been, for too long, an embarrassing slogan given the deteriorating realities on the ground. The initiative did not target such central principles of democratic governance as government accountability, transparency and participation. Neither 
has the mutually reinforcing nature of the goals to reduce poverty, promote gender equality and improve governance been duly highlighted in the national MDGs framework. Mongolia's case strongly suggests that the design of governance goals and the methodology of assessing and monitoring their progress should be given careful consideration. The country's experience also suggests that it is important for national leaders in new democracies to fully embrace and own the goals and targets of poverty reduction and democratic governance -- and to lead. And they should be held accountable for the failures in the implementation.

The impending Community of Democracy discussions in Ulaanbaatar will provide Mongolian leaders both in government and in civil society with an opportunity to reflect on the current status of the country's MDGs on poverty reduction and democratic governance and commit to their acceleration. It should be noted that the latest poverty figure shows a decrease-29 percent in 2011 versus 39 percent in 2010-but it is yet to be determined if this is attributable to government's untargeted cash handouts of the past three years, or whether it points to a trend. Whichever the case, sustaining economic growth and expanding the opportunities offered by it, especially by reducing youth unemployment, will be essential if the country is to meet its goal of reducing poverty to 18 percent by 2015. The discussion will also help the thinking on the best ways to incorporate the "unfinished business," or any unmet MDGs, into the country's post-MDGs goals in a way that is mindful of the importance of the wider governance context for any success in the key areas of poverty, gender equality and environment.

After years of stalled reform that threatened to jeopardize the country's democratic gains, it appears that the Mongolian government is now more willing to tackle its outstanding governance issues. It has laid out its plans to reform the civil service, judiciary and police, the institutions most frequently cited in past surveys as the most corrupt; wider policy deliberation and citizen feedback and participation are encouraged, including through the use of new technologies; democracy education is being debated; efforts to address corruption have been stepped up and a more robust national strategy to combat it is in the works. A recent survey showed a slight increase in the level of confidence that people place in the ability of the country's anti-corruption agency to tackle the issue. In a promising sign, in a single year, the country moved up 26 places in its ranking of the Transparency International's Corruption Perception Index (the effect of changes in methodology and lesser number of countries surveyed is unclear). The government has also expressed its intent to join the Open Government Partnership (OGP), a multilateral transparency initiative involving governments and civil society. Its OGP Action Plan is scheduled to be presented later this month. 
The government's commitment to accountability and transparency will be put to the test by its handling of the case of a former finance minister*, whose failure to disclose his offshore company and a secret Swiss bank account, holding \$1 million at one time, was brought to light last week by the International Consortium of Investigative Journalists (ICIJ).

If sustained, reform should improve government effectiveness and create an enabling governance environment for focusing on poverty eradication which should remain the government's first priority. In the years ahead, the country's significant extractive wealth will also have to be managed in an exemplary way so that its benefits go to the entire population in an equitable way. The CD's position that eradication of poverty is essential for a healthy democracy should serve as a guiding principle for the Mongolian government for it to regain public trust and produce outcomes that ensure prosperity, justice and security for the people.

Since the next CD ministerial will take place in 2015, only a couple of months removed from the global gathering on development, the Ulaanbaatar CD ministerial is an opportunity for democracies to start working together to include the democratic principles of accountability, transparency and participation into the post-2015 poverty eradication agenda. A reaffirmation of the CD's belief in the mutually reinforcing nature of democracy and development can also help re-shape the debate in Mongolia in a way that integrates eradication of poverty, equity and social justice into the broader project of democracy.

* Note: Mr. S. Bayartsogt, deputy chairman of the State Ih Hural, Mongolian Parliament, at the time of the writing 